\title{
POSTHATCHING DEVELOPMENT OF THE STOMACH OF TILAPIA NILOTICA (OREOCHROMIS NILOTICUS). LIGHT AND ELECTRON MICROSCOPIC STUDIES
}

\author{
El- Habback H. A.
}

Department of Cytology \& Histology, Faculty of Veterinary Medicine, Cairo University.

\section{ABSTRACT}

In this study, the stomach of Oreochromis niloticus fish was examined during their growth from the time of hatching to the adult stage using light and TEM. At the time of hatching the digestive tract was represented by undifferentiated tube located dorsal to the yolk sac. Differentiation of the digestive tube into oesophagus, presumptive stomach and intestine by the second day posthatching. In addition to the appearance of dense secretory granules in the first part of the stomach (cardiac) lining epithelium that reacted only to PAS. Mucous glands were also detected at the cardiac by the day seven after hatching. These glands reacted positively with PAS and alcian blue stain. As the larva grew, acidophilic glands lined by cuboidal cells reacted negatively for both PAS and alcian blue started to appear in the second part of stomach (fundic) at nine days posthatching. Fine structure of these glands revealed large basal euchromatic nucleus, free ribosomes, dilated $r E R$., well developed Golgi, complex system of tubules and vesicles and the numerous large mitochondria with tubular cristae. By the ten days after hatching, mucous glands began to appear in the third part of the stomach (pyloric). At the ultrastructure level, the glandular cells were joined to each other by multiple desmosomes. Their cytoplasm was mostly occupied by electron dense granules of different sizes and densities. By 14 days after hatching the stomach was completely formed. Physiological implications of some ultrastructure features were also discussed. 


\section{INTRODUCTION}

Phases in fish ontogeny have been established according to the way of feeding, external features, such as morphometric data or pigmentation, and characteristics related to locomotion and mobility (Balon, 1975, 1985; Barnabe' et al., 1976). However the larval periods involve extensive maturational changes in the internal organs, especially the digestive tract. The development of the fish alimentary canal especially the stomach has mainly been considered according to anatomical or histological criteria (Tanaka, 1971; Vu, 1980; O'Connell, 1981; Albertini-Berhaut, 1987; Loewe and Eckmann, 1988; Pedersen and Falk-Petersen, 1992; Boulhic and Gabaudan, 1992; Gisbert et al., 1998; Ribeiro et al., 1999a; Hernandez et al., 2001). The feeding habits of fish larvae have been correlated with stomach structure (Stroband and Kroon, 1981; Luizi et al., 1999; Roo et al., 1999). Several enzymes related to digestion have also been considered (Stroband et al., 1979; Vu, 1983; Ribeiro et al., 1999b). At the ultrastructural level, apart from a complete investigation on the development of the stomach in Dicentrarchus labrax (Hernandez et al., 2001) and gilthead sea bream (Elbal et al., 2004) only a few data about stomach of certain fish larvae have been reported (Stroband and Kroon, 1981; Connes and Benhalima, 1984; Albertini-Berhaut, 1988 and Deplano et al., 1991a,b).

Tilapia nilotica is a teleost of high commercial value. In this species, the stomach structure at both light and electron microscopic levels, and some histochemical reactions, have previously been reported in adults (Caceci et al., 1997; Gargiulo et al., 1997 and Morrison \& Wright, 1999). The aim of the present study was to determine the morphology, the ultrastructure and the carbohydrates of the epithelial gut 
cells during the ontogeny of Tilapia nilotica from hatching to 120 days and to relate them with physiological events. It is hoped that this information will help in the evaluation of digestive tract functional capacity and the physiology of digestion in larvae and be useful for the design of optimal rearing techniques and artificial feed for this species.

\section{MATERIAL \& METHODS}

Oreochromis niloticus (Tilapia) were obtained from a commercial breeder. The samples were collected daily from 0 day till 14 days (whole larvae), then weekly till 4 months after hatching (stomach).

For light microscope examination, 40 fish were used. The whole small sized fish (until the age of 14 clays) and the stomach samples from the larger ones were fixed in $10 \%$ neutral buffered formaldehyde then dehydrated, cleared, and embedded in Paraplast wax. Thin sections were cut and stained with: Harris hematoxylin and eosin (H \& E), Periodic acid Schiff (PAS) and Alcian blue (PH 1.0 \& 2.5). These methods were used as described by Drury \& Wallington (1980).

For TEM, $1.0 \mathrm{~mm}^{3}$ tissue samples of larvae and adult were obtained from different parts of the stomach. The tissue was immersed in 5.0\% glutaraldehyde buffered at PH 7.2-7.4 with $0.1 \mathrm{M}$ sodium cacodylate. After fixation, specimens were rinsed in the buffer, and immersed in $1.0 \%$ osmium tetroxide in $0.1 \mathrm{M}$ cacodylate at the same $\mathrm{PH}$. The tissues were then dehydrated, cleared in propylene oxide, and embedded in epon resin (Hayat, 1989). "Thick" survey sections (1.0 to $1.5 \mathrm{~nm}$ ) were cut with a glass knife, and stained with toluidine blue for light microscopy. Ultrathin sections were cut with a diamond knife, stained with uranyl acetate and lead citrate and examined using Jeol TEM 100 CX II at $80 \mathrm{Kv}$. 


\section{RESULTS}

\section{From newly hatched to 1-day-old larvae:}

Light microscopical examination of Oreochromis niloticus larvae immediately after hatching revealed that the digestive tract appeared as undifferentiated straight tube, located dorsally to the eosinophilic yolk sac (Fig. 1) and lined by a layer of columnar epithelial cells (Fig. 2). No folds, connective or muscular layer could be observed except for thin layer of myoblast cells (Fig. 2). The ultrastructure of the epithelial cells at this stage demonstrated an irregular surface and an undulated nucleus with granulular euchromatin and thin strands of heterochromatin with clear nucleolus (Fig. 3). The cytoplasmic organelles consisted mainly of numerous free ribosomes, polyribosomes, some rough endoplasmic reticulum cisternae (rER), numerous round or filamentous vacuolated mitochondria with a clear matrix and few irregular crests (Fig. 3) and Golgi complex. Apical tight junction could be also observed (Fig. 3) in addition to some tonofilament bundles. A thin layer of myoblast cells was also detected (Fig. 3).

\section{From 2- to 5-day-old larvae:}

Two days after hatching, the alimentary canal opened in the posterior part to form the anus. The digestive tube began to differentiate into oesophagus, presumptive stomach and intestine (Fig. 4). The goblet cells started to appear by the third day in the oesophagus. Folding of the mucosa and formation of propria- submucosa was slightly started by the fifth day posthatching. The muscular layer began to differentiate into circular layer by the second day posthatching as well as strands of striated muscle of the oesophagus extended toward the first part of the presumptive stomach (Fig. 5). The epithelial cells of the presumptive stomach were columnar and had some apical irregularities. Occluding Kafrelsheikh Vet. Med. J. Vol. 5 No. 2 (2007) 
junction was apparent clearly at the lateral cell membrane (Fig. 6). The irregularly contoured nucleus was euochromatic (Fig. 6). The cytoplasm was occupied by numerous free ribosomes, some vacuoles and dense granules located next to the apical surface (Fig. 6). Individual rER cisternae, a Golgi complex, and mitochondria with a clear matrix were occasionally seen. Moreover, tonofilaments were also determined (Fig. 6).

\section{From 6- to 8-day-old larvae:}

At this stage the mucosa of the presumptive stomach expressed more folding and the muscular layer began to be oriented into inner circular and outer longitudinal smooth muscle. The epithelial cells showed secretory activity represented by the appearance of apical granules that reacted positively to PAS (Fig. 7) and negative to alcian blue. The epithelial cells of the presumptive stomach showed numerous short apical microvilli, dense granules that were numerous in the supranuclear area, (Fig. 8). The cells were apically sealed by tight junction. A basal euchromatic nucleus, abundant mitochondria and numerous free ribosomes, dilated rER and well developed Golgi complex could be seen (Fig. 8).

The most apparent feature of this stage was the appearance of sporadic mucous gland cells inbetween the epithelial cells and in the propria- submucosa at the first part of the presumptive stomach by the day seven posthatching (Fig. 7). Fine structure of this region revealed short columnar cells that abut together by apical junction complexes, short desmosomes and interdigitations. The oval dense nucleus of irregular contour and a dilated nuclear envelope with a large nucleolus was located in the basal third of the cells. Dilated rER cisternae, a conspicuous Golgi complex of dilated cisternae were also found. Clear vesicles and mitochondria with a clear matrix and irregular crests were

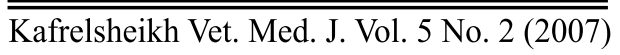


more numerous than in the epithelial cells of the presumptive stomach in previous age. Gradual increase in the size and number of the apical microvilli, as well as in the number of apical secretory granules (Fig. 9). Pale acinar cells began to appear between the epithelial cells (Fig. 9). They were characterized by irregular nucleus with marginated heterochromatin and clear nucleolus. The cytoplasm contained free ribosomes, diffuse rER, mitochondria, and many vesicles.

\section{From 8- to 14-day-old larvae:}

At this stage the yolk was markedly decreased, moreover tubular glands lined by cuboidal cells and had acidophilic cytoplasm began to appear in the propria- submucosa of the second part of the presumptive stomach by the day nine posthatching (Fig. 10). These glands recorded no reaction toward PAS and alcian blue. Consequently; the third part of the stomach were highly folded, consisted of one layer of cylindrical epithelium and had deep gastric pits (Fig. 11). Mucous acini started to be recognized by the day ten after hatching open into the lumen of the third part (Fig. 11). Moreover, striated muscles were obvious underneath the propria-submucosa (Fig. 11). As the fish grew; the numbers of gastric glands increased in the first and second parts and to alesser extend in the third part.

By 14 days after hatching the stomach was Y-shaped included three defined regions first, second and third and the yolk was completely disappeared.

\section{The First region:-}

This region was continuous with that of the oesophagus. The luminal epithelium reacted positively toward PAS only (Fig. 12) while the gland gave strong positive reaction for both PAS (Fig. 12) and alcian blue (Fig. 13). 
At the ultrastructure level, the lining epithelial cells were tall columnar with vesicular nuclei. The nuclei showed peripheral heterochromatin and clear nucleolus. The apical parts of the cells illustrated prominent microvilli and the cells joined with each others by junction complex including occluding junction and desmosomes (Fig. 14). The cytoplasm showed diffuse rER, free ribosomes, elongated dense mitochondria with clear cristae, many spherical to elongated secretory granules, some of them open into the apical surface (Fig. 14) and well developed Golgi apparatus.

Large mucous glands characterized by large pale mucous globules that occupied most of the cytoplasm and obscured the nucleus were also seen inbetween the epithelium of the first part and in the propriasubmucosa (Fig. 15). The cytoplasm of these glands was narrow (Fig. 15) and represented at the peripheral of the gland cells by few dilated rER, free ribosomes and mitochondria. Some of these glands opened directly at the lumen (Fig. 15).

\section{The Second region:-}

This region was found next to the first part forming a sac like and joined the third region on the other side. The luminal border of the lining epithelium gave positive reaction to PAS only while the gland gave no reaction (Fig. 21).

Examination by electron microscope revealed that this region was lined by tall columnar epithelium with basely situated nuclei. The nuclei had peripheral diffuse heterochromatin and obvious nucleolus (Fig. 16). The cytoplasm demonstrated numerous dilated rER, many less electron dense spherical to oval mitochondria with clear cristae. The dual association of rER around the mitochondria was clear in the supranuclear part (Fig. 16). Dense secretory granules were also detected in the Kafrelsheikh Vet. Med. J. Vol. 5 No. 2 (2007) 
cytoplasm, apical part of the cell and the lumen of the second part epithelium (Fig. 16). The cytoplasm showed also well developed Golgi apparatus and many vesicles. The apical part of adjacent cells showed occluding junction and interdigitation.

The propria -submucosa of this region contained many tubular glands that were lined by cuboidal epithelium. The glands were separated from each others by blood vessels (Figs. 17 \& 19). The gastric glandular cells had numerous prominent apical processes (Fig. 18). The cytoplasm had large basal euchromatic nucleus, free ribosome, dilated rER. and well developed Golgi complex (Fig. 18). The most noticeable features of these cells were the presence of prevalence of complex system of tubules and vesicles in addition to the numerous large mitochondria with tubular cristae (Fig. 18). The gastric cells were conjugated by apical tight junction (Fig. 18) and desmosomes.

\section{The third region:-}

This region was markedly associated with the second part of stomach. It was characterized by more folding and deep gastric pits (Fig. 20). It was surrounded by thick muscular coat formed mainly of striated muscle (Fig. 20). The apical part of the lining epithelium as well as the gland reacted severely to PAS (Fig. 21).

Fine structure of the epithelium of the third region was quite similar to that of second region but the most prominent feature was the glandular epithelium cells opened into the lumen. They were irregular in shape, had prominent microvilli and joined to each other by multiple desmosomes (Fig. 22). Their cytoplasm was mostly occupied by electron dense granules of various size and density (Fig. 22). The cytoplasm was scare and represented by free ribosomes, rER, few mitochondria and tonofilaments. Peripheral dilated Golgi saccules also scattered near to the lateral membranes. 


\section{DISCUSSION}

The digestive tract was an undifferentiated straight tube, located dorsally to the eosinophilic yolk sac and lined by a layer of columnar epithelial cells. This was true in other teleosts such as Leiostomus xanthurus (Govoni, 1980), Engraulis mordax (O'Connell, 1981), Solea senegalensis (Sarasquete et al., 1996 and Ribeiro et al., 1999a) and gilthead sea bream (Elbal et al., 2004). The undifferentiation of the epithelium was confirmed by the presence of free ribosomes, few dilated rER and vacuolated immature mitochondria in the cytoplasm of the epithelium lining the digestive tube (Elbal et al., 2004) and our study.

Two days after hatching, the alimentary canal of Oreochromis niloticus opened in the posterior part to form the anus. The digestive tube began to differentiate into oesophagus, presumptive stomach and intestine. The differentiation of the digestive tract started in Sparus aurata larvae before the onset of exogenous feeding since the oesophagus, the presumptive or primordial stomach and the intestine were distinguished 3 days after hatching, before the opening of the mouth, (Sarasquete et al., 1995). Although the basic mechanisms of larval development do not differ greatly among teleosts, there is some interspecific variability in the timing at which the different ontogenetic events occur (Blaxter, 1988). The sequence of these events in Oreochromis niloticus was similar to that reported in other sparids (Miyazaki et al., 1991) as well as in other marine teleosts (O'Connell, 1981; Morrison, 1993;

Segner et al., 1995).

$\overline{\text { Kafrelsheikh Vet. Med. J. Vol. } 5 \text { No. } 2 \text { (2007) }}$ 
As the age proceed, the mucosa of the Oreochromis niloticus presumptive stomach expressed more folding and the epithelial cells showed secretory activity represented by the appearance of apical granules that reacted positively to PAS. The early differentiation and regionalization of the digestive tract in such a short period of time is a common feature of marine finfish species developing from small pelagic eggs, since yolk-sac reserves are depleted soon after hatching, and larvae need to start to feed exogenously at early stages of development (Mai et al., 2005). The moderately electron-dense granules at the supranuclear area of the epithelial cells lining the gastric region of Oreochromis niloticus larvae at 6-8 days posthatching are probably neutral mucosubstances, since their appearance coincides with the first detection of these substances in the gastric epithelial cells by the PAS method.

In the work presented, the most apparent feature was the appearance of sporadic mucous gland cells inbetween the epithelial cells and propria- submucosa at the first part of the presumptive stomach by the day seven posthatching. The classification of the stomach in Oreochromis niloticus corresponding to cardiac, fundic and pyloric regions of mammals was identified by (Caceci et al., 1997). The cardiac glands increased progressively to occupy the propria- submucosa as the larva grew. These glands reacted strongly positive toward PAS and alcian blue. These reactions mostly indicated the presence of neutral and acid mucosubstances. The acid mucosubstances were shown to be chiefly of the carboxylate and sialylated type. In fish, neutral mucosubstances Kafrelsheikh Vet. Med. J. Vol. 5 No. 2 (2007) 
secreted by the stomach epithelium have been related to the absorption of easily digested molecules, such as disaccharide and short-chain fatty acids (Grau et al., 1992). The mucosubstances facilitate the movement of large-sized food particles, as well as protecting the gastric mucosa from mechanical injury. The presence of both neutral and acid mucosubstances was observed in the superficial gastric epithelium of the white sturgeon (Domeneghini et al., 1999) and in developing larvae and adults of Sparus aurata (Domeneghini et al., 1998).

At nine days posthatching tubular glands lined by cuboidal cells and had acidophilic cytoplasm began to appear in the propria submucosa of the second part of the presumptive Oreochromis niloticus stomach. The gastric glands appeared in the Oreochromis niloticus larvae about the nine days post hatching, earlier comparing to the other fish species such as, Scophthalmus maximus (Cousin and Baudin-Laurencin 1986), Solea solea (Boulhic and Gabaudan 1992), Acipenser baeri (Gisbert et al. 1999) and pikeperch (Teresa, 2005). The gastric glands in pike-perch occurred in both cardiac and blind sac. In Paralabrax maculatofasciatus larvae they were found only in the anterior part of the stomach (Peña et al. 2003).

Fine structure revealed that the gastric glandular cells of the Oreochromis niloticus had numerous prominent apical processes, large basal euchromatic nucleus. The cytoplasm contained free ribosomes, dilated rER, well developed Golgi complex and

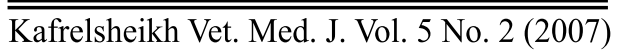


characterized by the prevalence of a complex system of tubules and vesicles and the numerous large mitochondria with tubular cristae. This architecture was quite similar to that described in Tilapia species. indicating that the fundic gastric glands secreted hydrochloric acid only (Gargiulo et al. 1997) and also in Dentex dentex (Carrasson et al., 2006).

As the age proceeded, the third part of the stomach became highly folded and consisted of one layer of cylindrical epithelium. Mucous acini started to be recognized by the day ten after hatching open into the lumen. These glands were irregular in shape and joined to each others by multiple desmosomes. The glandular cells were mostly occupied by electron dense granules of various size and density. The presence of many desmosomes between the pyloric glandular epithelium could reinforce their connection and made a strong framework supporting the glandular tissue during the secretion process (Gisbert et al, 2004). In this study these electron dense secretory granules might represent neutral mucosubstances confirmed by their strongly positive reaction to PAS. This type of secretion probably play a vital role together with that secreted by cardiac glands to protect the digestive mucosa from auto-digestion processes caused by hydrochloric acid produced by fundic gastric glands (Mai et al. 2005). We speculated that complete sealing of the pyloric glands by many desmosomes could also guarantee and enable the coupe of the large amount of secretion at one shot to neutralize the high acidity of the fundic glands which constituted the most population of the gastric glands in Oreochromis niloticus. 
The complete differentiation of the digestive system in large yellow croaker was achieved with the differentiation of pyloric caeca and gastric glands between 17 and 21 days after hatching, indicating the end of the larval period and the transition to the juvenile stage (Mai et al. 2005). The same was the case in Oreochromis niloticus suggested that the stomach was not functional until 10 days posthatching and consequently early juvenile age could be recognized at the same age.

From hatching until close to 5 days after hatching, Oreochromis niloticus larvae depended exclusively on their yolksac reserves, while a period of mixed nutrition based on endogenous reserves and exogenous feed was noted up to 6-10 days after hatching. This period is considered as one of the most critical events during larval early life stages, since short delays in feed availability influence posterior larval growth and survival (Teresa, 2005). In Chinese hatcheries, the transition from endogenous to exogenous nutrition often results in high mortalities of large yellow croaker larvae, which might be attributed to nutritional and/or infection problems (Mai et al. 2005). Different authors have implicated bacteria with problems of larval rearing in different finfish species (Gatesoupe, 1990; Nicolas et al., 1989; Padros et al., 1993; Gisbert et al., 2004).

The presence of striated muscle in the cardiac region and pyloric region of Oreochromis niloticus might be a means of disposing of unwanted material, either by regurgitating it, or by passing it rapidly along to the intestine (Morrison \& Wright, 1999). 


\section{LIST OF FIGURES}

Fig. (1): Longitudinal section through one day old larva showing the undifferentiated digestive tube $(\mathrm{T})$ on the dorsal aspect of the yolk (Y). H \& E stain, X 130.

Fig. (2): An ultrathin section through the undifferentiated digestive tube of 1 day old larva illustrated the columnar lining epithelium (E) and a thin layer of myoblasts (arrow) surrounded the tube. Toluidine blue stain, X 1025

Fig. (3): Electron micrograph of the digestive tube lining epithelium of one day larva showing euchromatic nucleus $(\mathrm{N})$, vacuolated mitochondria (m) and individual cisternae of rER (r). Notice the tight junction (arrows) and the myoblasts (arrow heads). Uranyle acetate- Lead citrate, X 3000

Fig. (4): Longitudinal section through two days old larva revealed the differentiation of the digestive tube into oesophagus (O), presumptive stomach (S) and intestine (I). H \& E stain, X 200.

Fig. (5): Longitudinal section through two days old larva showed the extension of striated muscle (arrows) from the oesophagus $(\mathrm{O})$ toward the presumptive stomach (S). H \& E stain, X 410.

Fig. (6): Electron micrograph of the presumptive stomach lining epithelium of two days old larva showing euchromatic nucleus $(\mathrm{N})$, free ribosomes (R), vacuole (V), tonofilaments (open arrows), secretory granules (closed arrows). Notice the occluding junction (arrow heads). Uranyle acetate- Lead citrate, X 4000

Fig. (7): The first part of the stomach of seven days posthatching larva showing the appearance of the mucous gland (g) that reacted strongly positive with PAS while the apical part of the lining epithelium (E) only gave positive reaction (arrow). PAS technique, X 410 . 
Fig. (8): Electron micrograph of the presumptive stomach lining epithelium of 6 days old larva demonstrated the nucleus $(\mathrm{N})$, dilated rER (r), well developed Golgi apparatus (G), mitochondria (m), dense secretory granules (large arrows) and short apical microvilli (small arrow). Uranyle acetate- Lead citrate, X 3000

Fig. (9): Electron micrograph of the first part (cardiac) of developing stomach lining epithelium of 7 days old larva revealed apical microvilli (curved arrow), occluding junction (arrow), desmosome (arrow head) and interdigitation (I). The cytoplasm had dilated rER (r), mitochondria (m), Golgi complex (G), small vesicles (Vs) and secretory granules (S). Note the acinar cells (A). Uranyle acetateLead citrate, X 5000

Fig. (10): Longitudinal section through the stomach of nine days old larva showed the junction between the cardiac of the stomach (C) that contained mucous gland (g) and the second part (fundic) of stomach (F). Notice the appearance of acidophilic glands (arrow) in the second part of stomach. H \& E stain, X 410

Fig. (11): Cross section through the stomach of ten days old larva showed the appearance of the gastric glands (g) in the third part (pyloric) of the stomach. Note the deep gastric pit (arrow) and striated muscle (S). H \& E stain, X 410.

Fig. (12): A section of the cardiac region of the stomach of adult fish showing that the epithelium lining (arrow) and the cardiac glands (g) reacted positively for PAS. PAS technique, X 410.

Fig. (13): A section of the cardiac region of the stomach of adult fish showing the cardiac glands (g) only contained alcian blue positive materials. Alcian blue stain, X 410.

Fig. (14): Electron micrograph of the cardiac stomach lining epithelium of adult fish revealed apical microvilli (curved arrow), occluding junction (arrow), desmosome (arrow head). The cytoplasm had dilated rER (r), mitochondria (m) and secretory granules (S) that concentrated at the apical part. Note the acinar cells (A). Uranyle acetate- Lead citrate, X 10000 
Fig. (15): Electron micrograph of the cardiac stomach showing apical microvilli (arrow), mucous glands (m) and their thin narrow cytoplasm (arrow head). Uranyle acetate- Lead citrate, X 6000

Fig. (16): Electron micrograph of the fundic stomach lining epithelium of adult fish revealed the nucleus $(\mathrm{N})$, the close association of rER (r) and less electron dense mitochondria $(\mathrm{m})$ and dense secretory granules (arrows) that concentrated at the marginal part of the cell. Uranyle acetate- Lead citrate, X 15000

Fig. (17): An ultrathin section of the fundic stomach showed the columnar lining epithelium (E) and the fundic glands (g) lined cuboidal epithelium and separated by blood vessels (B). Toulidine blue stain, X 1025.

Fig. (18): Electron micrograph of the fundic glands of adult fish illustrated apical cell processes (arrow head) and joined by tight junction (arrow). The cytoplasm demonstrated the nucleus $(\mathrm{N})$, large tubular mitochondria (m), well developed Golgi complex (G) and complex system of tubules and vesicles (T). Uranyle acetate- Lead citrate, $\mathrm{X}$ 19000

Fig. (19): Electron micrograph of the fundic glands (g) of adult fish separated by blood vessels. Note the endothelium (E) lining the blood vessels and the erythrocyte (arrow). Uranyle acetate- Lead citrate, X 15000

Fig. (20): A section through the pyloric stomach of adult fish showed the mucous gastric glands (g), the deep gastric pit (arrow) and striated muscle (S). H \& E stain, X 410.

Fig. (21): Longitudinal section at the junction between the fundic (F) and Pyloric (P) stomach. Notice that the apical parts of epithelium (arrow) and the pyloric glands (g) reacted positively with PAS while the fundic glands(F)gave no reaction. PAS technique, X 410.

Fig. (22): Electron micrograph of the pyloric glands (g) of adult fish illustrated apical microvilli (arrow) and many desmosomes (arrow heads) at the lateral sides of the glandular cells. Uranyle acetate- Lead citrate, X 22000. 

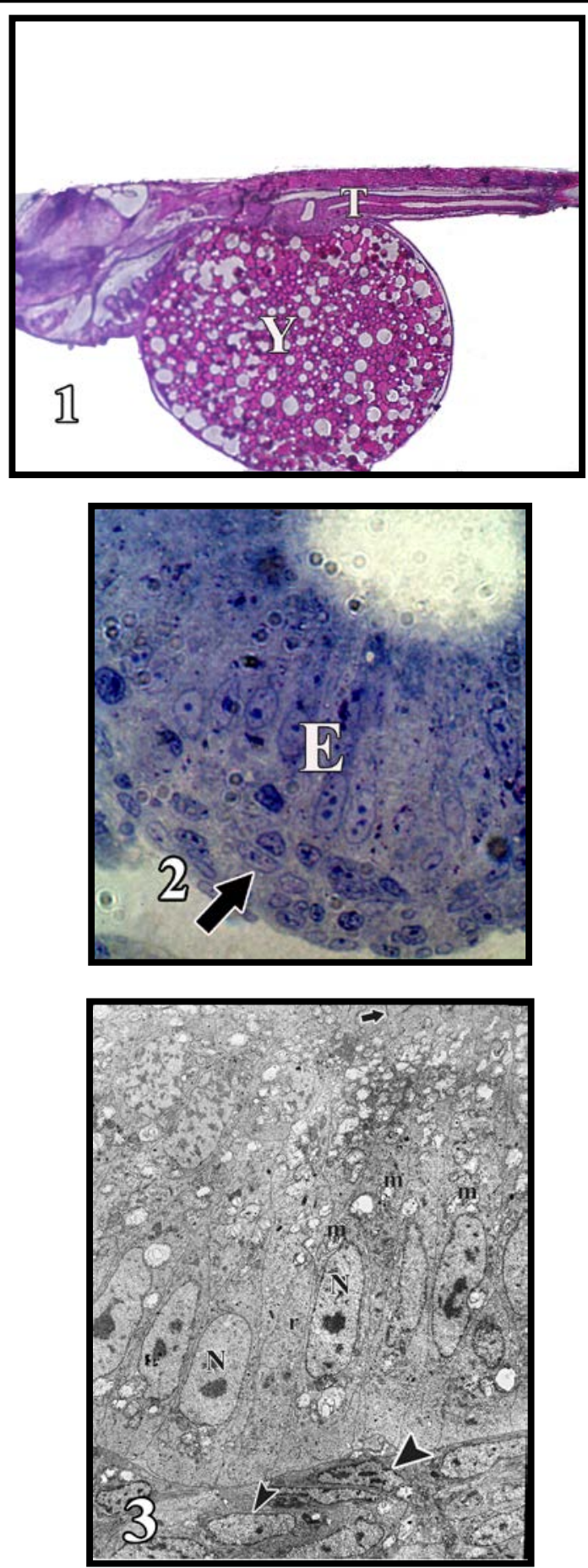

$\overline{\text { Kafrelsheikh Vet. Med. J. Vol. } 5 \text { No. } 2 \text { (2007) }}$ 
El-Habback H. A.
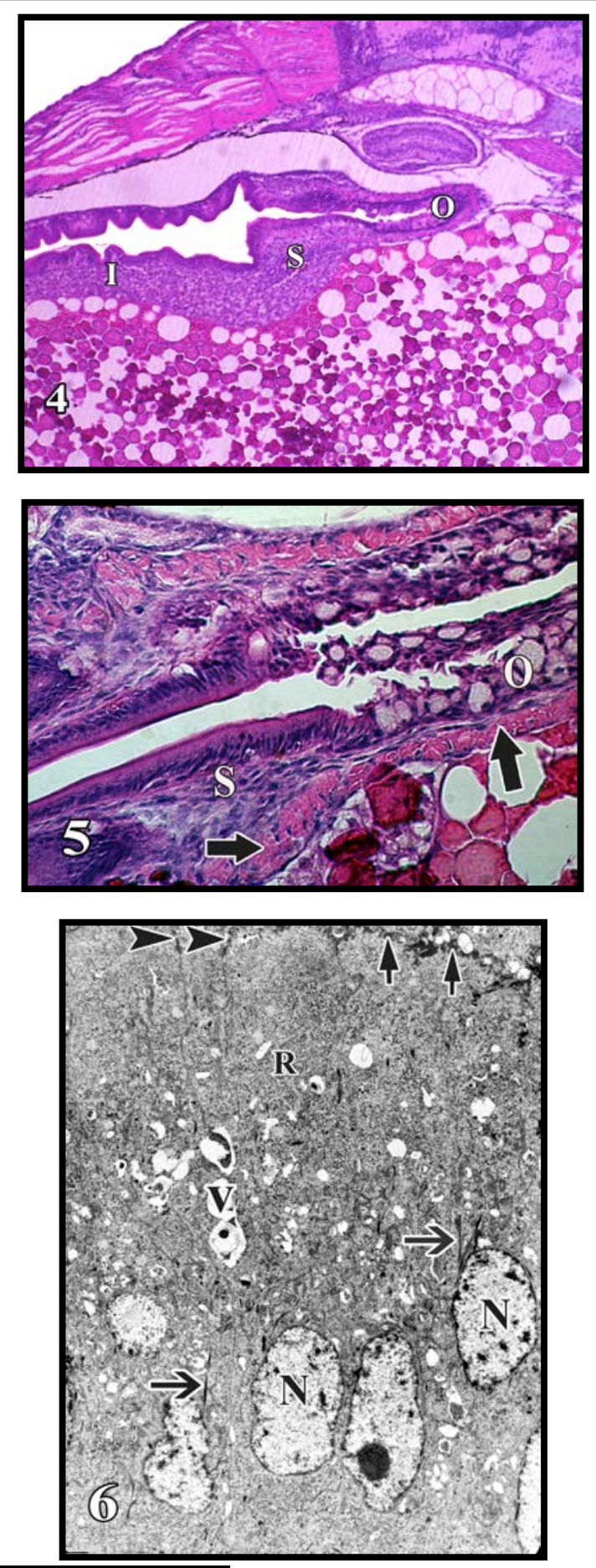

$\overline{\text { Kafrelsheikh Vet. Med. J. Vol. } 5 \text { No. } 2 \text { (2007) }}$ 
Posthatching Development Of The Stomach Of Tilapia Nilotica ...

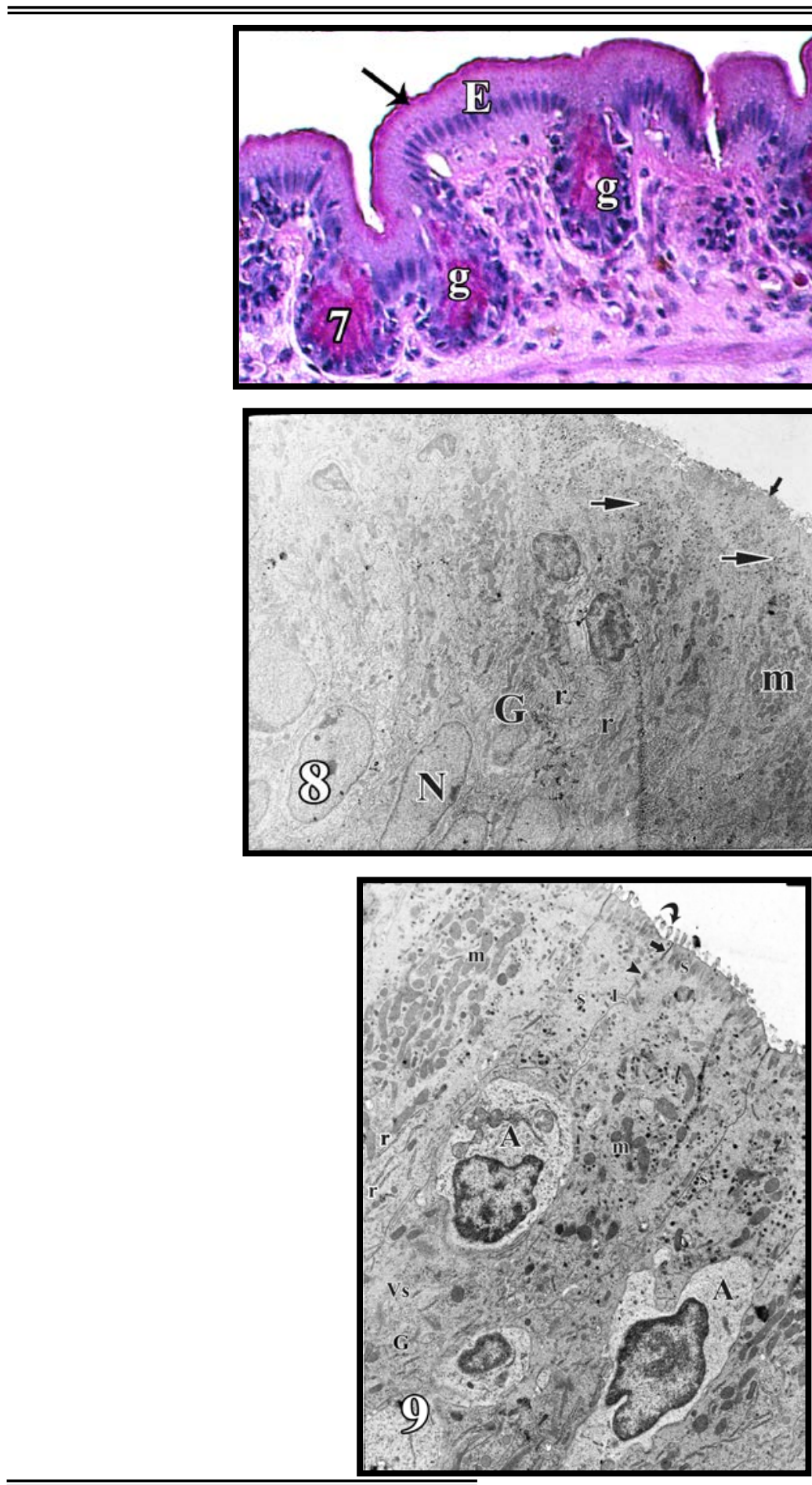

$\overline{\text { Kafrelsheikh Vet. Med. J. Vol. } 5 \text { No. } 2 \text { (2007) }}$ 
El- Habback H. A.
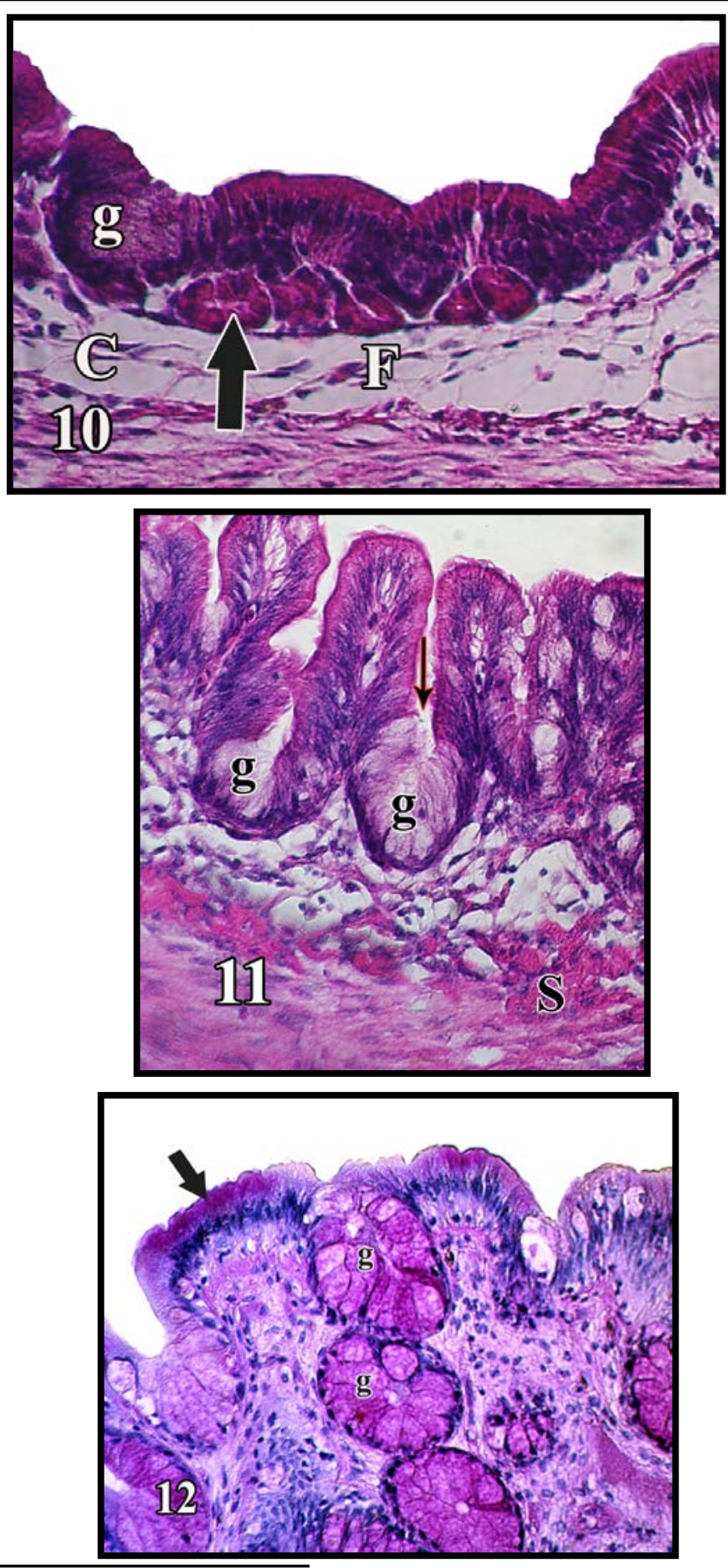

$\overline{\text { Kafrelsheikh Vet. Med. J. Vol. } 5 \text { No. } 2 \text { (2007) }}$ 
Posthatching Development Of The Stomach Of Tilapia Nilotica ...
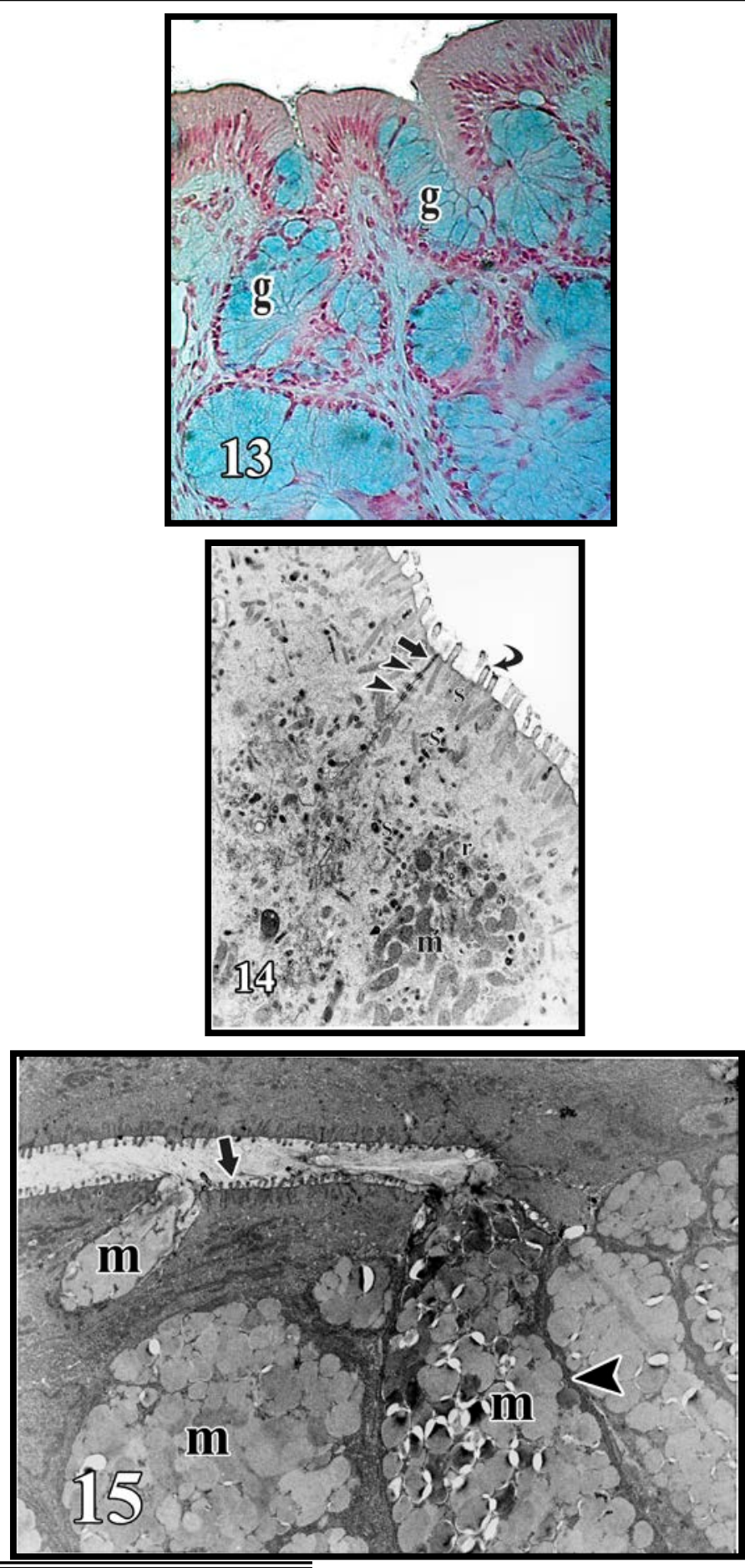

$\overline{\text { Kafrelsheikh Vet. Med. J. Vol. } 5 \text { No. } 2 \text { (2007) }}$ 

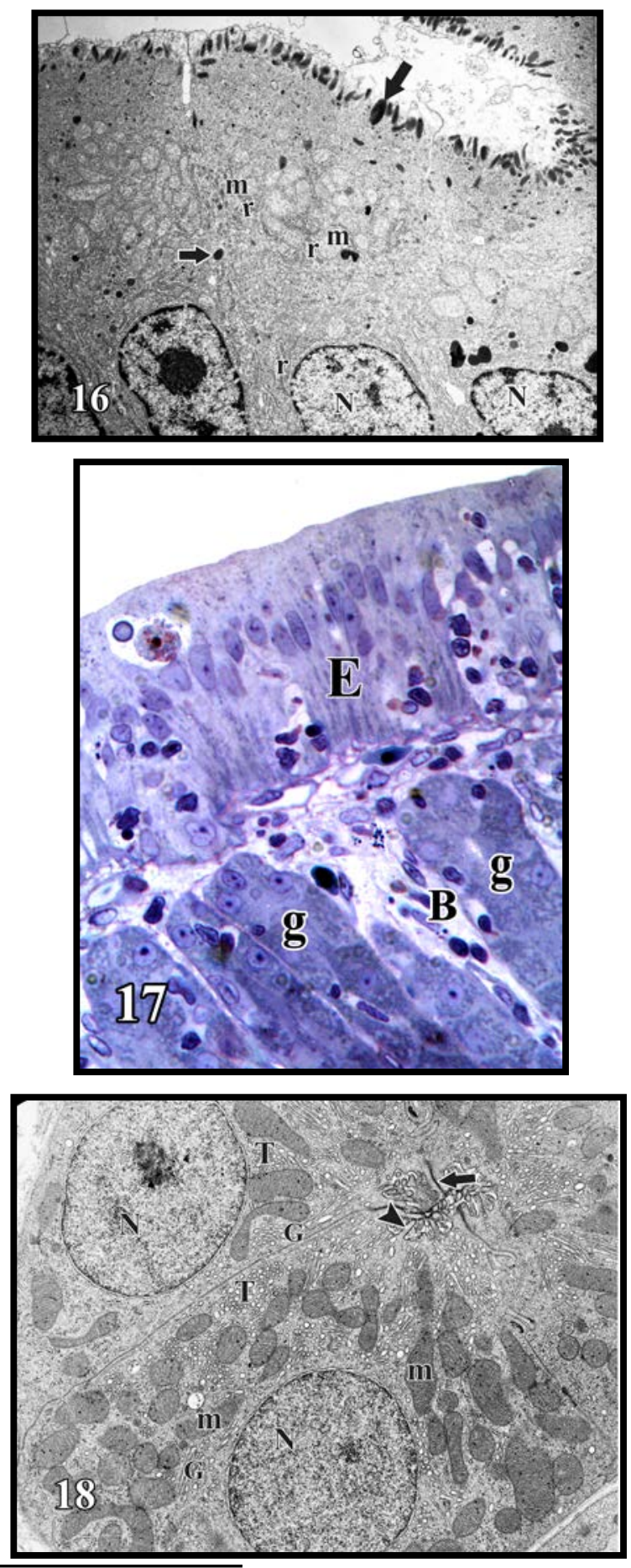

$\overline{\text { Kafrelsheikh Vet. Med. J. Vol. } 5 \text { No. } 2 \text { (2007) }}$ 
Posthatching Development Of The Stomach Of Tilapia Nilotica ...
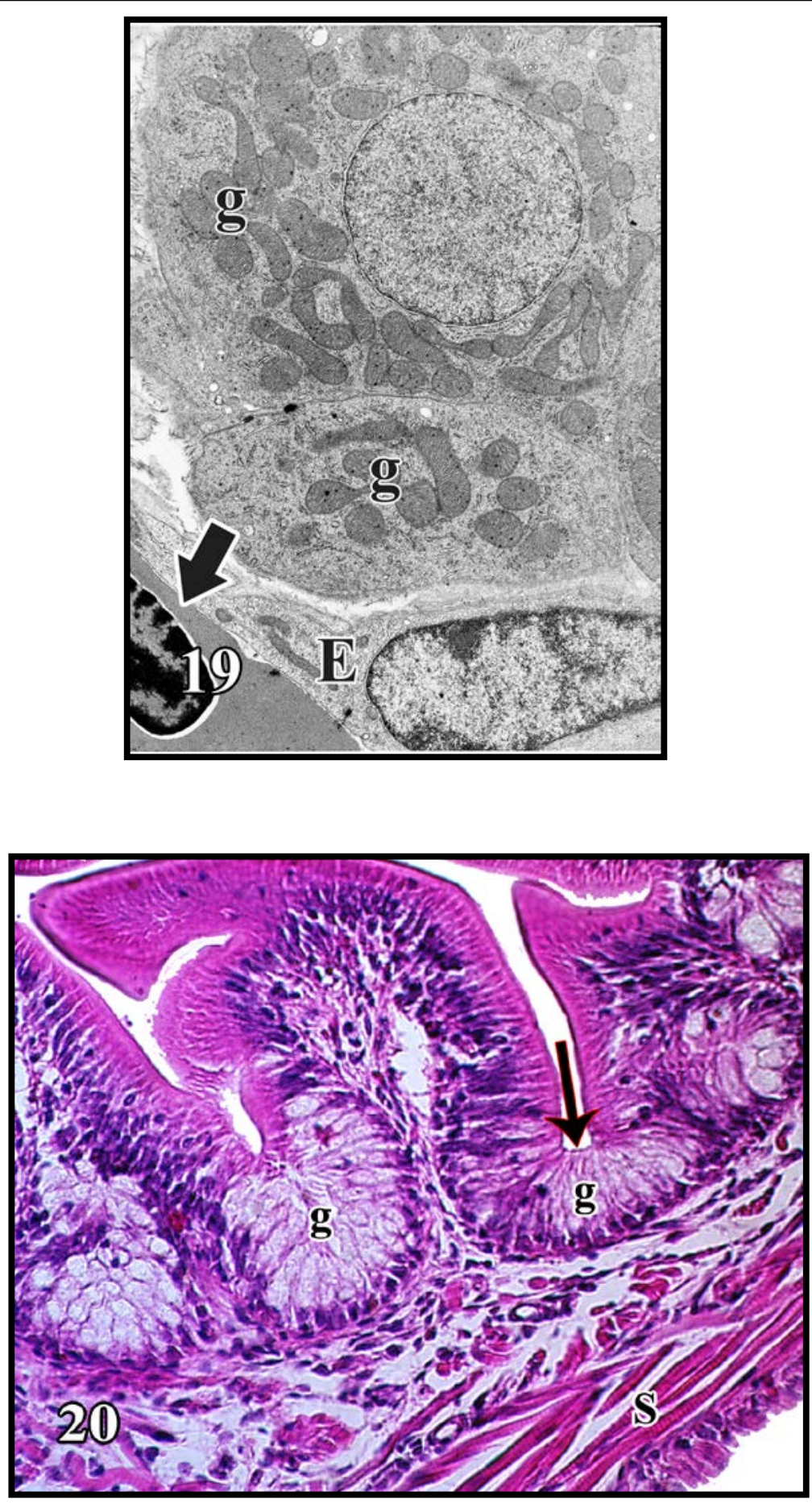

$\overline{\text { Kafrelsheikh Vet. Med. J. Vol. } 5 \text { No. } 2 \text { (2007) }}$ 
El- Habback H. A.
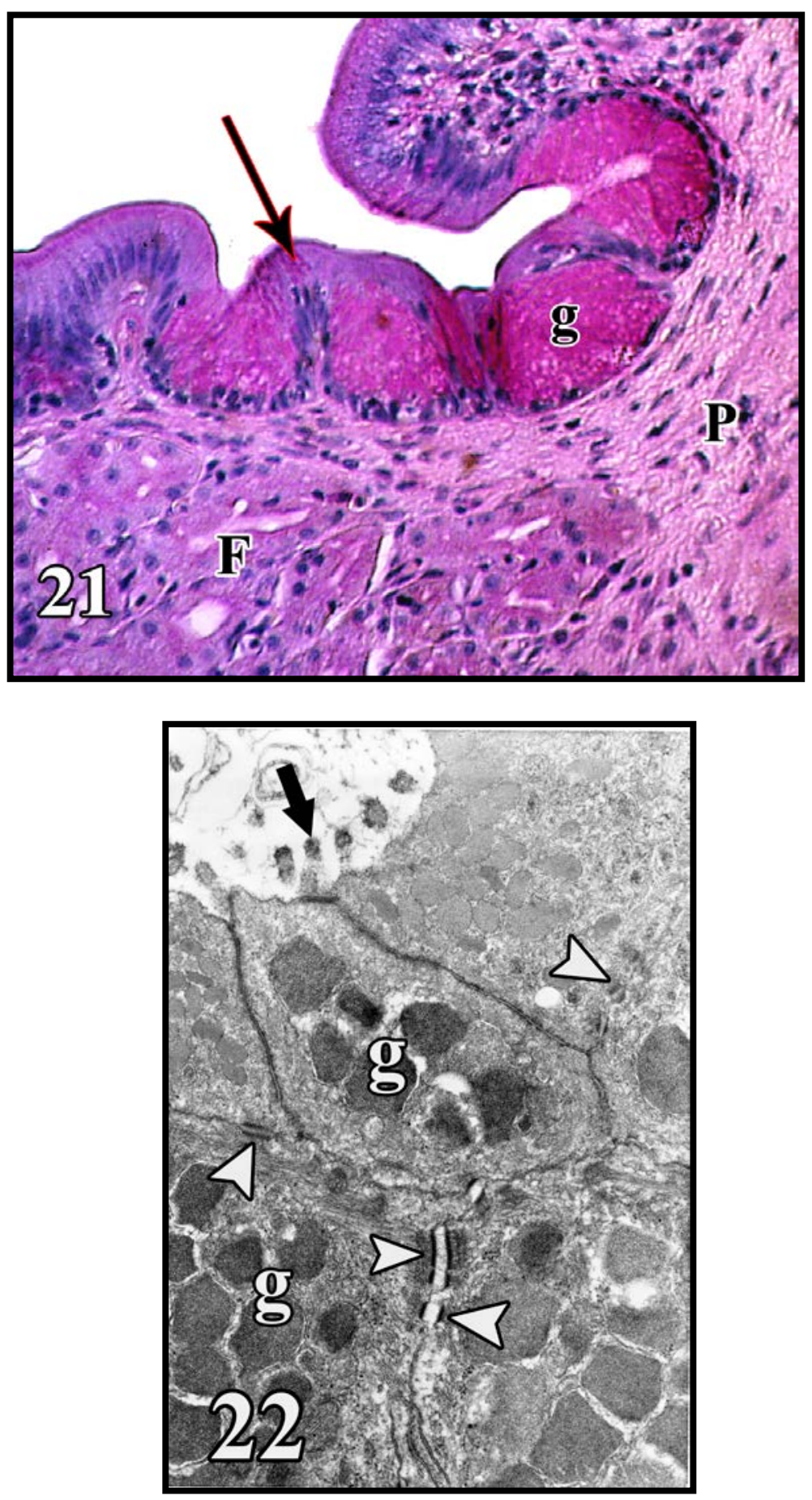

$\overline{\text { Kafrelsheikh Vet. Med. J. Vol. } 5 \text { No. } 2 \text { (2007) }}$ 


\section{REFERENCES}

- Albertini-Berhaut,J.,(1987). L'intestin chez les Mugilidae (Poissons; Téléoste'ens) a` diffe'rentes e'tapes de leur croissance: I. Aspects morphologiques et histologiques. J. Appl. Ichthyol. 3, 1- 12.

- Albertini-Berhaut, J.,(1988). L'intestin chez les Mugilidae (Poissons; Téléoste'ens) a` diffe'rentes e'tapes de leur croissance: II. Aspects ultrastructuraux et cytophysiologiques. J. Appl. Ichthyol. 4, 65- 78.

- Balon, E.K., (1975). Terminology of intervals in fish development. J. Fish. Res. Board Can. 32, 1663 - 1670.

- Balon, E.K., (1985). The theory of saltatory ontogeny and life history models revisited. In: Balon, K. (Ed.), Early life histories of fishes: new developmental, ecological and evolutionary perspectives. Dr. W. Junk Publishers, Dordrecth, pp. 13-28.

- Barnabe', G., Boulineau-Coatanea, F., Rene, F. \& Martin, V., (1976). Chronologie de la morphogenese chez le loup bar Dicentrarchus labrax (L.) (Pisces Serranidae) obtenu par reproduction artificielle. Aquaculture 8, 351-363.

- Blaxter, J.H.S., (1988). Pattern and variety in development. In: Hoar, W.S., Randall, D.J. (Eds.), Fish Physiology, vol. XI. The physiology of developing fish, Part A. Eggs and Larvae. Academic Press, London, pp. 1 -58.

- Boulhic, M. \& Gabaudan, J., (1992). Histological study of the organogenesis of the digestive system and swim bladder of the Dover sole, Solea solea (Linnaeus 1758). Aquaculture 102: 373-396. 
- Caceci, T., El-Habback, H., Smith, S. A. \& Smith, B. J., (1997). The stomach of Oreochromis niloticus has three regions. J. fish biology 50, 939-952.

- Carrsson, M., Grau, A., Dopazo, L. R. \& Crespo, S., (2006). A histological, histochemical and ultrastructural study of the digestive tract of Dentex dentex (Pisces, Sparidae). Histol. Histopathol. 21(6). 579-593.

- Connes, R. \& Benhalima, K., (1984). Ultrastructure de l'intestin du loup Dicentrarchus labrax L. au cours du de'veloppement larvaire. Bull. Soc. Zool. Fr. 109, 19-33.

- Cousin, J.C.B. \& Baudin-Laurencin, F., (1986). Morphogénése de l'appareil digestif et de la vessie gazeuse du turbot, Scophthalmus maximus L. Aquaculture 47: 305-319.

- Deplano, M., Connes, R., Di'az, J.P. \& Barnabe', G., (1991b). Variation in the absorption of macromolecular proteins in larvae of the sea bass Dicentrarchus labrax during the exotrophic phase. Mar. Biol. 110, 29- 36.

- Deplano, M., Di'az, J.P., Connes, R., Kentouri-Divanach, M. \& Cavalier, F., (1991a). Appearance of lipid-absorption capacities in larvae of the sea bass Dicentrarchus labrax during transition to exotrophic phase. Mar. Biol. 108, 361- 371.

- Domeneghini, C., Arrighi, S., Radaelli, G., Bosi, G. \& Mascarello, G. S., (1999). Morphological and histochemical peculiarities of the gut in white sturgeon, Acipenser transmontanus. European J. Histochemistry 43, 135-145.

- Domeneghini, C., Stranini, R. P. \& Veggetti, A., (1998). Gut glycoconjugates in Sparus aurata L. (Pisces, Teleostei), a comparative histochemical study in larval and adult ages. 
Histol. Histopathol. 13, 359-372.

- Drury, R. A. B. \& Wallington, E. A. (1980). Carleton's histology techniques 5 th Ed. Oxford university press.

- Elbal, M. T., Garcia Hernandez, M. P., Lozano, M. T. \& Agulleiro, B., (2004). Development of digestive tract of gilthead sea bream (sparus aurata L.) Light and electron microscopic studies. Aquaculture 234. 215-238.

- Gargiulo, A. M., Ceccarelli, P., Dall'Aglio, C. \& Pedini, V., (1997). Ultrastructure study on the stomach of Tilapia spp. (Teleostei). Anatomia, Histologia \& Emberyologia 26(4). 331336.

- Gatesoupe, F.J., (1990). The continuous feeding of turbot larvae, Scophthalmus maximus, and control of the bacterial environment of rotifers. Aquaculture 89, 139- 148.

- Gisbert, E., Piedrahita, R. H. \& Conklin, D. E., (2004). Ontogenetic development of the digestive system in California halibut (Paralichthys californicus) with notes on feeding practices. Aquaculture 232, 455-470.

- Gisbert, E., Rodriguez, A., Castello'-Orvay, F. \& Williot, P., (1998). A histological study of the development of the digestive tract of Siberian sturgeon (Acipenser baeri) during the ontogeny. Aquaculture 167, 195- 209.

- Gisbert, E., Sarasquete, M.C., Williot, P. \& Castello, F., (1999). Histochemistry of the development of the digestive system of Siberian sturgeon (Acipenser baeri, Brandt) during early ontogeny. J. Fish Biol. 55, 596-616.

- Govoni, J.J., (1980). Morphological, histological and functional aspects of alimentary canal and associated organ 
development in larval Leiostomus xanthurus. Rev. Can. Biol. 39, 69- 80 .

- Grau, A., Crespo S. O, Sarasquete, M. C. \& Gonzales de Canales M. L., (1992). The digestive tract of the amberjack Seriola dumerii, Risso: a light and scanning electron microscope study. J. Fish Biol. 41, 287-303.

- Hayat, N.A.,(1989). Principles and techniques of electron microscopy, biological application 3 rd Ed., Aspen publisher Inc. Rockville, Maryland.

- Hernandez, G.M., Lozano,M.T., Elbal, M.T. \& Agulleiro, B., (2001). Development of the digestive tract sea bass (Dicentrarchus labrax L.). Light and electron microscopic studies. Anat. Embryol. 173, 1- 19.

- Loewe, H. \& Eckmann, R., (1988). The ontogeny of the alimentary tract of coregonid larvae: normal development. J. Fish Biol. 33, 841- 850.

- Luizi, F.S., Gara, B., Shields, R.J. \& Bromage, N.R., (1999). Further description of the development of the digestive organs in Atlantic halibut (Hippoglossus hippoglossus) larvae, with notes on differential absorption of copepodod and Artemia prey. Aquaculture 176, 101- 116.

- Mai, K., Yu, H., Ma, H., Duan, Q., Gisbert, E., Zambonino Infante, J. L. \& Cahu, C., (2005). A histological study on the development of the digestive system of pseudosciaena crocea larvae and juveniles. J. fish Biol. 67(4). 1094-1106.

- Miyazaki, T., Fujiwara, K., Oka, H.P. \& Yoshikawa, M., (1991). Histological studies on development of tissues and 
organs of larval and juvenile red sea bream. Bull. Fac. Bioresour. Mie Univ. 5, 97-116.

- Morrison, C. M. \& Wright, J. R., (1999). A study of the histology of the digestive tract of the Nile tilapia. J. fish biology 54(3), 597-606.

- Morrison, C.M., (1993). Histology of the Atlantic cod, Gadus morhua: an atlas. Part four: eleuthero embryo and larva. Can. Spec. Publ. Fish. Aquat. Sci. 119 (496 pp.).

- Nicolas, J.L., Robic, E., Asquer, D., (1989). Bacterial flora associated with a trophic chain consisting of microalgae, rotifers and turbot larvae: influence of bacteria on larval survival. Aquaculture 83, 237- 248.

- O'Connell, C.P., (1981). Development of organ systems in the northen anchovy, Engraulis mordax, and other teleosts. Am. Zool. 21, 429- 446.

- Padros, F., Minkoff, G., Sala, R. \& Crespo, S., (1993). Histological events throughout the development of turbot (Scophthalmus maximus L.) larvae. J. Comp. Pathol. 109, 321334.

- Pedersen, P. \& Falk-Petersen, I.B., (1992). Morphological changes during metamorphosis in cod (Gadus morhua L.), with particular reference to the development of the stomach and pyloric caeca. J. Fish Biol. 41, 449- 461.

- Peña, R., Dumas, S., Villalejo-Fuerte, M. \& Ortiz-Galindo, J.L., (2003). Ontogenetic development of the digestive tract in reared spotted sand bass Paralabrax maculatofasciatus larvae. Aquaculture 219: 633-644.

- Ribeiro, L., Sarasquete, C. \& Dinis, M.T., (1999a).

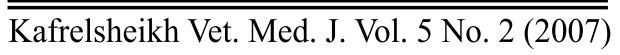


Histological and histochemical development of the digestive system of Solea senegalensis (Kaup 1858) larvae. Aquaculture 171, 293- 308.

- Ribeiro, L., Zambonino-Infante, J.L., Cahu, C. \& Dinis, M.T., (1999b). Development of digestive enzymes in larvae of Solea senegalensis, Kaup 1858. Aquaculture 179, 465- 473.

- Roo, F.J., Socorro, J., Izquierdo, M.S., Caballero, M.J., Herna'ndez-Cruz, C.M., Ferna'ndez, A. \& FernandezPalacios, H., (1999). Development of red porgy Pagrus pagrus visual system in relation with changes in the digestive tract and larval feeding habits. Aquaculture 179, 499- 512.

- Sarasquete, C., Gonzalez de Canales, M.L., Arellano, J.M., Muñoz-Cueto, J.A., Ribeiro, L. \& Dinis, M.T., (1996). Histochemical aspects of the yolk-sac and digestive tract of larvae of the senegal sole, Solea senegalensis (Kaup, 1858). Histol. Histopathol. 11, 881- 888. M.T. Elbal et al. / Aquaculture 234 (2004) 215-238 237

- Sarasquete, M.C., Polo, A. \& Yu'fera, M., (1995). Histology and histochemistry of the development of the digestive system of larval gilthead seabream, Sparus aurata, L. Aquaculture 130, 79-92.

- Segner, H., Storch, V., Reinecke, M. \& Kloas, W., (1995). A tabular overview of organogenesis in larval turbot (Sophthalmus maximus L.). ICES Mar. Sci. Symp. 201, 3539.

- Stroband, H.W.J. \& Kroon, A.G., (1981). The development of the stomach in Clarias lacera and the intestinal absorption of protein macromolecules. Cell Tissue Res. 215, 397- 415.

- Stroband, H.W.J., van der Meer, H. \& Timmermans, L.P.M., 
(1979). Regional differentiation in the gut of the grasscarp, Ctenopharyngodon idella (Val.). Histochemistry 64, 235- 249.

- Tanaka, M., (1971). Studies on the structure and function of the digestive system in teleost larvae: III. Development of the digestive system during post-larval stage. Jpn. J. Ichthyol. 18 (1), 64-174.

- Teresa, O., (2005). Developmental changes of digestive system structures in pike-perch (Sander Lucioperca L.). Electronic J. of Ichthyol. 2. 65-78.

- Vu,T.T.,(1980).E' tude histologique de l'e'pithe'lium du tube digestif du bar, Dicentrarchus labrax (L.) au cours du de'veloppment post- embryonnaire. Arch. Zool. Exp. Ge'n. 121, 191- 206.

- Vu, T.T., (1983). E' tude histoenzymologique des activite's protéasiques dans le tube digestif des larves et des adultes du bar. Dicentrarchus labrax (L). Aquaculture 32, 57- 69. 